\title{
The Politics of Language In Eritrea: Equality Of Languages Vs. Bilingual Official Language Policy
}

\author{
Redie Bereketeab \\ The Nordic Africa Institute \\ Uppsala, Sweden
}

\section{Email: redie.bereketeab@nai.uu.se}

Redie Bereketeab is a researcher at the Nordic Africa Institute, Uppala, Sweden. He holds $\mathrm{PhD}$ in Sociology from the Department of Sociology at Uppsala University, Sweden. He has written several articles and book chapters. He is also the author of Eritrea: The Making of a Nation, 1890-1991, the Red Sea Press (2007), and State Building in Post-liberation Eritrea: Challenges, achievements and potentials, Adonis \& Abbey Publishers (2009).

\section{Acknowledgement}

I am indebted to Kidane Hagos and Phyllis O’Neil therefore I extend my thanks to both. I will also extend my thanks to the anonymous reviewers.

\begin{abstract}
The article analyzes the discourse of politics of language in Eritrea. It argues that the language debate in Eritrea over equality of languages and bilingual official language policy is more about power relations than about language per se. It relates to politics of identity that derive from the construction of two identity formations as understood by political elites. Equality of languages is based on ethnic identity, whereas official language is based on the construction of supra-ethnic civic identity. According to the constructivist bilingual official language Arabic and Tigrinya are supposed to represent two different socio-cultural identity formations, notably, Islamic-Arabic and Christian-Tigrinya. Consequently, the official language policy debate could be construed to derive from politics of power relation where two groups of elites supposedly representing the two identity formations are engaged in power competition reflecting real or imaginary socio-cultural cleavage of respective identity. In this sense the bilingual official language is designed to create social equilibrium wherein it is supposed that power would equitably be distributed between two rival elite groups.
\end{abstract}

Keywords: Eritrea, Arabic, Tigrinya, politics of language, mother tongue, official language

\section{Introduction}

Arguably language furnishes the necessary underlying ingredient for the politics of identity. Language is considered to represent a key marker of identity. Identity in turn, in a polyethnic setting, constitutes the ground for language groups to make demands for the right of recognition. After all, recognition presupposes difference (Taylor 1994). When ethno- 
linguistic groups featuring substantial differences share common space and at the same time their relation is characterized by marked inequality there arise the need for politics of group rights and recognition. The politics of language could be described therefore as the area of study where the interrelationship between language, politics, and public life come together. As such, recently, the politics of language has gained an increasingly powerful position in the dynamics of state politics. As Kymlicka (1995: 111) notes, “languages rights are a fundamental cause of political conflict, even violence, throughout the world, including Canada, Belgium, Spain, Srilanka, the Baltic’s, Bulgaria, Turkey and many other countries”.

Since its inception as a colonial territory the issue of bilingualism has been a crucial preoccupation of socio-cultural life in Eritrea. The debate revolving around bilingual official language policy gripped the public realm following the demise of Italian colonial rule. The British Military Authority (BMA) that succeeded the Italians, probably induced by their political reading of the social fabric of the Eritrean society embarked on in earnest to cultivate a binary socio-linguistic society (cf. Trevaskis 1960; Longrigg 1945) based on Islam-Arabic and Christian-Tigrinya identity formations (Young 2008: 5, Hailemariam et al 1999: 477).

Partly, probably derived from its perception of the imperatives of the constitutive role of official language in the function of state formation, the UN-sponsored federation that went into operation in 1952, made all the efforts to make sure that the federal constitution of the autonomous state of Eritrea entails binding bilingual official language close (Bereketeab 2007). This, though, a source of pride and joy, engendered bitter difference between Eritrean elites (Tesfai 2005). Releasing its enduring implication for Eritrean identity, the imperial Ethiopian state responded by prohibiting Eritrean languages from public realms (GebreMedhin 1989, Habte Selassie 1989, Iyob 1995, Bereketeab 2007). It was only in the public space created by the national liberation movement that Eritrean languages could again resume having functions of public status.

The NLM created an alternative public space for Eritrean languages (Hailemariam 1999: 487). But, the two Fronts, the Eritrean Liberation Front (ELF) and the Eritrean People's Liberation Front (EPLF) pursued diverging language policy. While the ELF adopted a bilingual official language policy (ELF 1971); the EPLF pursued equality of language policy (Negash 1999, Gottesman 1998, Hailemariam et al 1999: 488). This difference was interpreted by many observers as influenced by the dominant socio-cultural political actors leading the Fronts. It was perceived that while the dominant force in the ELF was of ArabicIslamic socio-cultural background; the dominant force in the EPLF was of Tigrinya-Christian 
socio-cultural backdrop. What is interesting here was that even those of different sociocultural origin internalized the official language policy of the organization they joined.

The post-independence government of Eritrea introduced mother tongues as mediums of instruction at lower levels of education, while declaring all languages equal (Negash 1999, Gottesman 1998, Constitution 1997). The non-official language policy of the government led to acrimonious debate during the drafting of the constitution (Hailemariam et al 1999: 488) while small ethno-linguistic groups like the Kunama and Blin appreciated mother tongue education and consequently equality of languages, others were highly critical of the policy. Opponents of mother tongue education and non-official language policy wish to see Tigrinya and Arabic promoted to official status. This opposition comes primarily from Moslem communities. At bottom line the contestation concerns that the Moslem elites would like to engender equilibrium between two socio-cultural formations.

The objective of this paper is to analyze the debate revolving around language in Eritrea. It analyzes the current controversy surrounding official language and mother tongue policy in Eritrea. My point of departure is that the underpinning sociological factor for the division could be related to power relations. As such, theoretically, it could be explained through drawing on Bourdieu's thesis of language as symbolic power. To that end the paper endeavours to examine and analyze the connection between language, social and political identity and the associated power (both social and political) that each group attaches to its language and what is considered the rival language, and the social role elite rivalry plays in the controversy. It tries to address questions such as: is equality of languages (mother tongue) antithetical to official language? Is mother tongue necessary and sufficient for ethnic identity formation? How is mother tongue related to basic human and democratic rights? How important is official language for nation-state building process? What are the merits and demerits of tying state language policy to a bilingual official language policy?

\section{Language and Symbolic Power: Theoretical Framework}

This section sets the theoretical frame informing the analyses of the debate on the politics of language in Eritrea. It navigates through the notion of language as symbolic power in order to analyze the problematic of languages in Eritrea. The French sociologist Pierre Bourdieu, in his sociology of language, analyzes the relation between language and power. He expounds that language as a cultural symbol and as a communicational instrument plays a significant political power role. In his seminal work Language and Symbolic Power (1991), 
Bourdieu maintains that language is not merely a tool of communication but also a medium of power. In his sociological analyses of language, Bourdieu identifies the concepts of habitus and field as central underpinning functional tools. He explains the sociological intersubjective interaction persuasively and eloquently. "The habitus is a set of dispositions which incline agents to act and react in certain ways. The dispositions generate practices, perceptions and attitudes which are 'regular' without being consciously co-ordinated or governed by any 'rule'” (Bourdieu 1991: 12). Dispositions are arguably nurtured through systematic socialization and internalization mechanisms in which childhood phases constitute the start point in the formation and crystallization of dispositions. Further the dispositions are, along the process, structured where they reflect the social conditions in which they were constructed. Structured dispositions are durable, generative and transposable, according to the theory developed by Bourdieu (Bourdieu 1991: 13).

The second concept, field or market alludes to a specific structured space wherein people interact in which individuals or groups are pitched in social games “...to maintain or alter the distribution of the forms of capital specific to it” (Bourdieu 1991: 14). One of the conceivably salient properties of a field is its easily convertibility from one type of capital to another (e.g. cultural capital-education-to economic one-lucrative job). Translated into empirical social relation this convertibility of the field could be assessed differently than the ethno-linguistic group's social field; if not grounded on a level-field it not only necessarily leads to inequality and disadvantages, but also may lead to social relation whose characterizing feature becomes bitter rivalry and conflict. It is presumed that the rivalry and conflict is driven by the need of converting one's field into normatively coveted capital. Capital in all its forms constitutes social power

Bourdieu further talks about legitimate language. Legitimate language is, according to Bourdieu, the dominant language that assumes official status through asserting its legitimate competence in the linguistic market. He maintains that "linguistic market creates the condition for an objective competition in and through which the legitimate competence can function as a linguistic capital, producing a profit of distinction on the occasion of each social exchange” (Bourdieu 1991: 55). Legitimate language, in turn, produces individuals that possess legitimate language competence, that is, competence to adequately use and competently converse in the official language. Acquiring legitimate competence in the conversation with the official language confers upon one a capital, a capital that optimizes the standing of the individual in the commonly shared and coveted market. Bourdieu seems to try to tell us that it 
is the uneven distribution of the legitimate competence of the legitimate language that spawn discrepancy in capital and power relation among social actors and groups.

For Bourdieu capital consists of three types: (i) economic (material wealth-money, stocks and shares, property, etc.), (ii) cultural (knowledge, skill and other cultural acquisitions), and (iii) symbolic (accumulated prestige or honour) (Bourdieu 1991: 14). The lesson we can draw from Bourdieu's sociology of language is that the discrepancy in acquisition of the variety forms of capital enables certain groups or actors to dictate their wishes upon others. Those who possess the legitimate language competence, it is argued, also possess the ability to impose it as the only legitimate one in the formal market (Bourdieu 1991: 56). Bourdieu continues: "Legitimate competence is the statutorily recognized capacity of an authorized person - an 'authority'” (Bourdieu 1991: 69-70). The authority confers upon the person both legitimate legal standing in the public realm as well as increasing its competitive advantage. Those who lack legitimate legal standing certainly aspire to get it.

In Bourdieu's argument, two discernible aspects come out clearly. One aspect deals with the production and reproduction of legitimate language in the market where relations are determined by acquiring legitimate language competence that in turn determine the emergence of a class of victors and losers, at least initially. The second aspect deals with the consequent market produced victors and losers, where their relation is decisively expressed in their power relation, that is, while the victors enhance their political power capital, the losers are relegated to a lower status, or are compelled to assimilate in a condition set out by market victors. Understood and interpreted in this way the politics of language is easily converted into politics of power. In this sense Bourdieu's 'Language and Symbolic Power' lies the foundation for why and how the politics of language is converted into politics of power, and the field of language constitutes a field of political contestation, particularly among the various politico-cultural groups within a society. The field or market in a poly-ethnic sociological setting is understood as a cultural-political space where different ethno-linguistic groups enter into trade exchange in an institutionalized manner with the aim of usurping economic, cultural and symbolic capitals that are easily convertible into political capital. Bourdieu's sociology of language has inspired many scholars in the western World as well as in developing societies. Scholarship on developing societies made concerted efforts to translate Bourdieu's sociology of language into language relation of the polyglotic developing societies. Referring to Bourdieu's understanding of language Goke-Pariola maintains that such understanding leads to the perception that linguistic signs can be '... 'signs of wealth' (or poverty), and 'signs of authority' (or the lack thereof), 'intended to be believed or obeyed' 
(Goke-Pariola 1993: 222). Further, Goke-Pariola (1993: 223) notes language is perceived 'in the acquisition and maintenance of power, as something capable of bestowing upon, or denying to the user and great deal of symbolic profit, and by virtue of this, effecting the construction of the social reality of a society'. Therefore, language is seen beyond being merely a vehicle of communication, as indeed a cultural package. A package through which in addition to acquisition of skills of language use, one learns to accept values (Prah 2001: 7) and social position. Language for all intents and purposes can serve, in the socio-political power game, in retaining profitability in the market of linguistic capital. All this is contingent on social reality whose defining feature may vary considerably.

Quite often, of course, the social reality is conveniently constructed so that it would duly fit in the intellectually or elite mapped power relation. Nevertheless, arguably, intellectuals try to sell it out in the name of the masses. Bourdieu (1991: 57), referring to this phenomenon, argues, 'The defenders of Latin or, in other context, of French or Arabic, often talk as if the language they favour could have some value outside the market, by intrinsic virtues such as its 'logical' qualities; but, in practice, they are defending the market'. The market here represents a space or field where actors interact freely for the production and appropriation of strategic resources or capital, in this case linguistic capital where language occupies crucial strategic space. In saying this, Bourdieu expressly displays the inclination toward the instrumentalist perception of language. The theory of instrumentalism in the politics of language discernibly tends to stress that contestations reflect the instrumental value of language serving power and resource acquisition.

In this respect the production of linguistic capital takes place through endowing a sufficient and strategic dominant space in the field where production and allocation of the preferred language take place. This includes the use and organization of language and education. The bestowing upon Arabic this strategic dominant space instead of the mother tongue apparently fulfils this instrumental functional purpose.

Official language is presumed to be one that within a territorial limit of a political unit imposes itself on the wider population as the only legitimate language of the public sphere. The legitimacy may invariably be dictated by demographic, jurisdictional or both factors. Arguably, official language is bound up with the state, both in its historical genesis and its social-structural functions. Evidently, it is in the process of state formation that the conditions for the constitution of a unified linguistic market, dominated by the official language, are created (Bourdieu 1991: 45). Here Bourdieu is concerned with the sociological dimension of official language rather than with its legalistic and technical aspect. 
Official language, in polyethnic and polyglotic social settings, serves as lingua franca, as a means of communication at the public sphere level across ethno-linguistic groups (Anderson 1991, Mazrui and Mazrui 1998). It could be seen as a political arrangement that facilitates understanding and interaction between the various ethno-linguistic groups in specifically defined and confined political and juridical spheres. In other words it is a language of the polity and jurisdiction. Therefore, there is a high possibility that it might not have anything to do with ethnic or primordial cultural identity. It might not also be a language spoken by the majority. Those states in Africa that use English, French, Spanish, and Portuguese as official language are typical examples (Anderson 1991). All this indicates that official language could be an instrument of communication, quite often serving the upper echelons of society at the public sphere rather than used by the layman at a grassroots level. It is also quite often a language of institutions in schools and universities in which case it may be assigned an instructive role. In this sense, the evolution of a language to an official status pursues both sociological and jurisdictional processes and mechanisms.

On the other hand, the emergence of an official language could be seen as an arrangement of convenience, rather a result of complex negotiational and dialogical compromises aiming at the elite. In that sense official language represents high culture (cf. Gellner 1983), whereas mother tongue may represent low culture-folkloric tradition. In so far as they stand for high culture and low culture, official language and mother tongue express relation of opposition. It is not unusual that, in the eyes of the elite, mother tongue is seen as a symbol of backwardness, primitiveness and savagery, where elites look at it with contempt, feel ashamed to be heard using it in public (cf. Webb 2002); while official language could represent the opposite. Moreover, mastering the official language means what Bourdieu (1991: 56) calls possessing legitimate competence, and vests upon one knowledge, power and status.

Conversely, mother tongue could be seen as representing a group's value system, norms and identity. This is so because, unlike official language (lingua franca), mother tongue serves in the daily life of the common person. People need not go to school to learn it; to know its codes, the most unuttered, still yet, valuable bedrock of a culture that convey subtle meanings and interpretations. It begins to develop at the same time a child begins breastfeeding and learns the first word with the utterance of that word by his mother. They are socialized in it by their parents and their community, and later internalize it in their daily life in a natural way. Moreover, what is socialized and internalized need to be externalized, transcending from the subjective mental sphere to the objective social-psychological sphere. 
In a nutshell, they express their feeling, thoughts and actions, from the very rudimentary to the most sophisticated ones, through it. As such, therefore, it has a direct bearing to primordial cultural identity. In this sense, language as a system of expressions of one's thoughts and feelings occupy a predominant position in social and human development.

\section{Brief Historical Background of the People and Languages of Eritrea}

Eritrea is located in the strategically important region known as the Horn of Africa. To the south it is bordered by Ethiopia, to the southeast it is bordered by Djibouti; to north and northwest shares its borders with the Sudan; and to the east with the Red Sea. Its strategic location has always been a point of attraction to foreign powers. Therefore, the Ottomans, Egyptians, Italians, British and Ethiopians alternated in occupying the territory. In its present politico-territorial form, Eritrea was created by Italian colonialism in 1890. Following the defeat of Italy in 1941, Eritrea was place under British Administration. By UN resolution, Eritrea was tied with Ethiopia in a federal arrangement that was put into operation in 1952. The abrogation of the federation in 1962 by Ethiopia led to annexation of the country, which already was preceded by the launching of armed liberation struggle (Gebre-Medhin 1989, Iyob 1995, Bereketeab 2007). After thirty years of liberation struggle against Ethiopia, Eritrean became independent in 1991. Eritrea's area is $121,320 \mathrm{~km}^{2}$. Its population is estimated to be $5.6^{1}$ million (The World Factbook 2009).

An interrogation into the constellation and genealogical origin of Eritrean society would give a picture of highly conflated and malleable constitutive pedigree. At a generic level it would be quite possible to identify three distinctively delineated families. These are: Nilo-Saharan, Cushitic ${ }^{2}$ (Afro-Asiatic) and Semitic (Hailemariam 1999: 485; Bender 2000, Chapter 3; Hayward 2000: 80). Eritrea's earliest inhabitants were believed to be the NiloSaharan who moved from the sick bush of South-Eastern Sudan. Later came the CushiticBadawi/Beja (Bender 2000: 80) from Northern Sudan and settled in the Barka region and northern highland. Last in this train of migration were the Semitic who crossed the Red Sea from Arabia (Trevaskis 1960: 4). The Semitic were believed to be the most influential group because they brought with them a highly advanced civilization. In addition to this there could

\footnotetext{
${ }^{1}$ There is no information about the exact size of the population of Eritrea. So far no census has taken place. Any figure is an estimation therefore it has to be taken with grain of doubt. The size of the population swings between 3.5 and 5.6 millions.

${ }^{2}$ While some make distinction between Cushitic and Hamitic others maintain that both describe to one and the same groups. Further, others to indicate the admixture of the two groups use the compound phrase HamiticCushitic (see Bender 2000)
} 
be mentioned a recent immigration to Eritrea. The Rashaida were believed to have crossed the Red Sea from Saudi Arabia in the late 1860s and settled in the coastal area of Sahil and western lowland along the Sudan-Eritrea border (Young 2008: 1, Tronvoll 1998: 27).

Further disaggregation of the three language families would provide a demographic configuration whose constellation would spawn the current nine ethno-linguistic groups occupying Eritrea. The Nilo-Saharan constellation consists of Kunama and Nara whose natural habitat is the Gash region; the Cushitic consists of Afar, Saho, Blin and Badawi/Beja (Beni Amir and Hidareb); the Semitic consists of Tigrinya, Tigre and Rashaida (Bereketeab 2007: 50-1, Hayward 2000: 80). The Afar lives along the southeastern coast of the Red Sea; the Saho share their habitat with Tigrinyans and Tigre, while the Blin live in the Senihit region and the Badawi/Beja occupy the Barka region. Of the two Semitic groups the Tigre lives mainly in the Semhar and Sahil regions, while the Tigrinyans live in the southern plateau. The Cushitic tribes in the lowland came under direct control and influence of the Axumite Kingdom "as consequence of which the less remote abandoned their harsh Hamitic dialects to the soft Semitic Ge'ez of their Axumite rulers” (Trevaskis 1960: 5). Appraised from ethnolinguistic dimension the Semitic groups would consist of 80-90 percent of the population (Young 2008: 5, Hailemariam et al 1999: 486).

Nevertheless, it could be illustrated, over history, profound intermingling between the various ethnolinguistic groups has taken place. This extensive historical cross-pollination and hybridization of demographic and genealogical pedigree of Eritrean society presents a higher degree of conflation than often is recognized. To shed light on this point I will take two examples: that of the Tigrinyans and Blin ethno-linguistic groups. According to genealogical mythology the Tigrinyans were thought to descend from two mystic ancestors, Meroni who had three sons, Faluk, Chaluk and Maluk who inhabited the regions of Akkele Guzai, and Hamasen (Tronvoll 1998: 50). The Seraye region was inhabited by a group called Adkeme Miliga who were thought to be descendants of early Agua from Lasta, Ethiopia (Trevaskis 1960: 11, Nielsen 2002: 79). The Blin ethno-linguistic group comprises two main sections: Bet Tarqe and Bet Tauqe. “The Bait Tarqay were Hamites and immigrants from Agua in Ethiopia; the Bait Tauqay were Tigrinya from the plateau. The Bait Tarqay brought with them the Hamitic dialect used in Agua, which they subsequently passed on to the Bait Tauqay and which has since developed as a distinctive dialect” (Trevaskis 1960: 15). Contrary to this fact, however, the commonplace perception is that Blin as a whole were descendents of Agua. This admixture and changes certainly apply to all ethno-linguistic groups which make the Eritrean society highly mixed and sociologically mosaic. 
Overall, thus, Eritrea consists of nine mother tongues (languages). According to their demographic ratio, in a descending order, they could be presented as: Tigrinya (50\%), Tigre ${ }^{3}$ (31.4\%), Afar (5\%), Saho (5\%), Hedareb (2.5\%), Blin (2\%), Kunama (2\%), Nara (1.5\%), Rashaida (0.5\%) (Negash 1999: 49). In the contested Eritrean politics, quite often this demography is reduced into a dichotomy of Christian highlanders and Moslem lowlanders. Further, either guided by political expediency or lack of adequate knowledge, the ratio of this dichotomy is also put into contention. Partisan claims, for political expediency, would exaggerate its own size while underestimating the size of "other". Also ill-informed "neutral" observers may also muddy the picture. A few examples are "The Christian Abyssinian comprised more than two-third of the Eritrean population” (Trevaskis 1960: 46). The Moslem League, however, had the contrary view that it was the Moslem's that constituted 75 percent of the society (Tesfai 2001: 334). This demographic distribution certainly impinges upon the linguistic and political distribution of power. The differential power distribution, in turn, may have given risen to the designing of strategies in order to countervail the demographically induced imbalance which at times extends to a level where its end result may have the effect of breaking up the Eritrean nation. One of such strategies is assembling the eight ethnolinguistic groups professing Islam into one block and the ethnic Tigrinyans into another in order to create social equilibrium.

Eritrea and Ethiopia are probably the only two countries in post-colonial sub-Saharan Africa that have their own written indigenous languages used at the public sphere. Almost all sub-Saharan Africa use the language of their ex-masters for public sphere purposes (BrockUtne 2000, Mazrui and Mazrui 1998). While Eritrea is pursuing all language equal policy, Ethiopia is pursuing a monolingual official language policy under ethnolinguistic federalism.

Let's now examine the evolvement of Eritrean languages in more detail. The primary focus will be on Tigrinya and Arabic as it is around them that language controversy revolves. But first on the mother language of Tigrinya-the Ge'ez. The oldest language that was in use by the Axumites, which today is used only in the church by the Coptic Church, was Ge'ez. In the Axumite Kingdom Ge'ez served as the language of people and the state from the $4^{\text {th }}$ to $11^{\text {th }}$ century. With the decline of the Axumite Kingdom, it was thought that Ge'ez lost its status as a spoken language. Yet writing in Ge'ez continued after the demise of the Axumite Kingdom until the $19^{\text {th }}$ century and was referred as Lisane Sehuf-the language of literature

\footnotetext{
${ }^{3}$ Here Tigre includes all Tigre speakers: those of Semitic origin and Cushitic origin. While Tigre speakers in Semhar, Senihit and Sahil (Habab, Marya, Betjuk, etc.) are of Semitic origin, the Beni Amir are of Cushitic pedigree. It seems that the few studies that exit give contradictory accounts on how the Beni Amir converted to Tigre tongue. That is also no unequivocal account of the ratio of the Beni Amir within the Tigre speakers.
} 
(Negash 1999: 63). Ge'ez is a Semitic language that was thought to have come to the region with the migrating Sabaean people from South Arabia (Ostler 2005: 92). It was thought to be a language of one of the tribes (Longrigg 1945: 16) also known as Aga'azean (Gebre Medhin 2004: 16). It is widely thought that Ge'ez played the role that was played by Greek and Latin in Europe in influencing local languages and cultures. Tigrinya and Tigre were presumed to have had derived from Ge'ez (Ostler 2005: 92). Of the two Eritrean languages, Tigre (spoken in the lowland of Eritrea) was presumed to be the first to derive from Ge'ez (Longrigg 1945: 16) followed by Tigrinya and Amharic. According to Edward Ullendorff (1973: 124), however, Tigrinya derived first followed by Tigre and Amharic. Ullendorff's inference seems to be based on the fact that Ge'ez was the language of the Axumite Kingdom, the habitat of the Tigrinya speakers, thus, it is logical to presume that the first language to derive from it should be Tigrinya. Literary heritage of Tigrinya could only be traced back to the 1880s (Hailemariam et al 1999: 485).

Concerning Arabic language, practically there exist no academic work as to its origin and introduction to Eritrea. A number of possible factors could have been involved in its introduction. The most obvious factor was the historical expansion of Islam. As Nicholas Ostler (2005: 96) notes, “Arabic established itself as the language of religion, wherever Islam was accepted, or imposed". Through what is known as the hijra al-ula (the first emigration) where followers of the prophet Mohammed landed at the Eritrean coast in AD 615 (Miran 2009: 167), Islam was brought to Eritrea. Hence, Arabic as the literary of the Holy Book (Koran) was introduced to Eritrea. Further Egyptian imperial expansion, trade, migration and the annual pilgrimage to Mecca might have contributed to the galvanization of Arabic language in Eritrean (Miran 2009, Hailemariam et al 1999: 486). The "Islamic Revival” in the late $18^{\text {th }}$ and through $19^{\text {th }}$ century (Miran 2009: 172) also was a contributing factor. The expansion of education in the $20^{\text {th }}$ century and subsequent close tie with Sudan and Egypt might have had a strong impact on Eritrean Moslem lowlanders in developing Arabic language. Nevertheless Arabic remained for a long time as a tongue of the aristocracy. It was probably in the early $20^{\text {th }}$ century that students of ordinary origin were able to travel to the Middle East to study that might have boosted Arabic in Eritrea. By the second half of the $20^{\text {th }}$ century, as Negash (1999: 51) notes, “indeed particularly the intelligentsia, have a near-native knowledge of both 'spoken and written’ Arabic”.

The development of Eritrean languages, particularly Tigrinya and to a lesser degree Tigre, got immense upswing in conjunction with emergence of Missionary and colonialism (Hailemariam 1999: 485-6). The significance of Missionary and Missionary schools in 
boosting Tigrinya and Tigre was that they translated the Bible in both languages (Negash 1999, Bereketeab 2007: 232-7). Tigrinya got further uplift when, in the 1930s, Italian colonial authorities began printing two pages in Eritrean languages in the Italian newspaper Quotidiano Eritrea; they used Tigrinya and Arabic (Negash 1999: 57). The development of Tigre, however, faced hurdles. It entered in competition with Arabic; some Moslem Tigre speakers preferred Arabic.

The greatest leap so far, however, came in conjunction with the commencement of the BMA. By 1943 the BMA began training teachers in Arabic and Tigrinya. Arabic text books from Egypt and Sudan were imported, while Tigrinya books were also published (Trevaskis 1960: 33). Weekly newspapers in Tigrinya and Arabic were also published by the Ministry of Information (Trevaskis 1960: 34). Beginning in 1946, when political parties were allowed, further advancement of Tigrinya and Arabic was also registered, thanks to the emergence of official party newspapers.

The usage of the two languages in the public realm experienced a dramatic uplift during the British Administration and the Federation period due to the proliferation of political parties and the emergence of an autonomous Eritrean state furnished with its own languages. The newspapers published by the Eritrean political parties until they were banned by the Ethiopian state also were either bilingual or came out either in Tigrinya or Arabic (Negash 1999: 57). Hanti Ertra (One Eritrea, 1950-1952) appeared in Tigrinya, whereas its successor Dehai Ertra (The Voice of Eritrea, 1952- 1954) appeared in Tigrinya and Arabic (both belonged to the Independence Bloc). Sout al Rabita al Islamiya (The Voice of the Islamic Alliance) appeared in Arabic. Etiopia (Ethiopia, 1947-1962) and Andinet (Unity, 1950-1962) were given in Tigrinya and Arabic, both belonged to the Unionist Party (UP). Zemen (The Times, 1953-1962) that replaced Eritrean Weekly News appeared in both languages. Zemen was published by the Eritrean Government.

The use of Tigrinya and Arabic in the public sphere gradually undermined Tigre. The debate on official language of the emerging autonomous state of Eritrea was extremely acrimonious. While the Unionists insisted in Tigrinya as the only official language, the Moslem League (ML) insisted on Arabic and Tigrinya. Amidst the heated debate, at one point, while some Unionists suggested Amharic instead of Arabic, the ML countered by suggesting only Arabic should be the official language (Tesfai 2005: 168-173). The Unionists opposed Arabic because they considered it as a foreign language and came with a suggestion of Tigrinya and Tigre (Negash 1999: 60, Tesfai 2005: 67, 170). They challenged the ML by referring to countries like Pakistan, Iran and Indonesia which are Moslem but did not adopt 
Arabic as their official language. At the end, however, as the UN drafted Constitution prescribed, Tigrinya and Arabic were taken as official languages of the autonomous Eritrean state. The adoption of the Eritrean Government of Tigrinya and Arabic as official languages in 1952, thus undermined Tigre (Ullendorff (1973: 124, Negash 1999: 60).

The era of the second Chief Executive (Mr. Asfaha Woldemichael)-1955-1962witnessed systematic dismantling of the provisions of the federation of which one dealt with the issue of languages. Following the abrogation of the Federation (1952-1962) Eritrean languages were completely banished from the public realm that threw them into the twilight zone of oblivion. To make sure that Eritrean languages, particularly Tigrinya, were sealed off the public sphere and forgotten, many Tigrinya books were burned (Negash 1999: 10, Hailemariam et al 1999: 481). Pursuant to the commencement of the liberation movement in 1961, however, an alternative public realm was to open for the Eritrean languages (Hailemariam 1999: 487).

The alternative space that was provided for the Eritrean languages was less permeated with political contestation and rivalry. The reason for this was that the order of priority was reset. Now what mattered was how to achieve sovereignty. The issue of official language(s) at a state level was relegated, for the time being, to the sphere of informality. In the first decade of the liberation struggle, for practical purposes and intentions, Arabic was the dominant means of communication within the Eritrean Liberation Front (ELF). In the second decade, however, the national liberation movement (NLM) witnessed a radical ethno-linguistic and socio-political change of composition of forces that necessitated reconsideration of language policy. Firstly, the NLM experienced massive participation of Christian Tigrinyans (Negash 1999: 51). Secondly, instead of one, two competing organizations shared the NLM space (Bereketeab 2007: 188-189). These two developments apparently gave rise to actively and purposively devising language strategies and policies. The ELF formulated its language policy in its First National Congress of 1971. In the Congress, the ELF took a decision that in effect would harness the development of all languages, though Tigrinya and Arabic were afforded the status of official language. The decision on languages read this way,

All national groups of Eritrea have the right to develop their languages in a way which encourages the development of a new revolutionary Eritrean culture (...) The two official languages of Eritrea, Arabic and Tigrinya shall be employed in all activities of the ELF (quoted in Negash 1999: 57) 
Nevertheless, the pledge made in 1971 to encourage the development of all languages was abandoned in the 1975 approved programme, the latter only reconfirmed the ELF's commitment on the status of Tigrinya and Arabic as official languages of the Organization (Negash 1999: 57). The Eritrean People's Liberation Front (EPLF), on the other hand, in addition to pursuing language policy that promoted development of all languages, its emphasis was on Tigrinya and Tigre. Although in practice Tigrinya and Arabic were used in EPLF's publications, media programmes, popular mobilizations, education and cultural activities (Negash 1999: 58). The language policy of the post-liberation Eritrean Government does not seem to differ very much from the EPLF's policy. The pre-liberation language policy was entrenched in the ratified Constitution (cf. Constitution 1997).

Our theoretical treatise expounds that the availability of a field endowed with capital to be readily competed and conquered locates language at the centre of political and social struggle. As we have seen in the theory section, the concepts of habitus and field could serve as significant conceptual tools in our endeavour of making sense of the Eritrean discourse of language and identity. Let's begin with the concept of field. The field represents a social space providing an ideal opportunity where resources are freely contested, shared, conquered and dominated. A vital element to bear in mind is that the field has to present itself as entailing common resources ready for social actors to initiate contest in the aim of capturing them. This indicates that if there is no field there is no resource, thus, no act of contest for actors. The field is where resources or capital production and reproduction take place. This situation can be illustrated by referring to two historical events that positioned the issue of language at the political centre in Eritrea. These were the emergence of the Federation in 1952 and the achievement of independence of Eritrea in $1991^{4}$. The two occasions, the UN sponsored Federation that produced the autonomous Eritrean state and the outcome of the thirty-year struggle post-liberation state, engendering the creation of the field produced and reproduced linguistic capital ready to be conquered. The state as an embodiment of resources or capital constituted a central legitimate target for the political actors' competition in their endeavour to appropriate a fair share of those resources. The issue of official language

\footnotetext{
${ }^{4}$ The UNGA (United Nations General Assembly) passed Resolution 390A (V) on 2 December, 1950 to federate Eritrea with Ethiopia. When the implementation of the UN-sponsored federal act of 1952 began, the issue of the official language of the autonomous state of Eritrea proved to be highly contentious. The parliament in its deliberation of the proposal spent seven solid days in a heated debate. The dispute emerged between two groups of elites leading two political parties, the Unionist Party and the Moslem League. The compromise struck at last gave tranquillity for a few years, until the federation was aborted and Eritrea annexed that brought to the forth other much greater issue of stake to Eritreans. Over the history of the liberation struggle the issue of language was not given greater space. It is only with the re-emergence of the Eritrean state in 1991 that it again resumed significance and became one of the divisive issues in post-liberation Eritrea.
} 
epitomized the contention because it was perceived as having a functional and instrumental value of a means to an end. When Eritrea was annexed, and thereby the availability of field ceased to exist, the contention on linguistic capital subsided only to emerge with enhanced vigour again with the rise of the field in the form of the independent Eritrean State in 1991. This demonstrates that for a linguistic contestation to emerge there has to be a free field ready to be conquered.

A word of caution, I am not here suggesting that it is merely an instrumentalist rationale that underpins the contention. I am aware that value rational of cultural identity also plays a significant undertone of the contention after all, 'Languages relate to values of sentiments and instrumentality’ (Mazrui and Mazrui 1998: 126). It is undoubtedly appealing to identify oneself with a language and a culture of a much wider magnitude and divine cosmological value; the appeal of Arabic may be fulfilling that quest. Nevertheless, the instrumentalist foundation of the contestation is also revealed vividly in the language and identity discourse in Eritrea. An instrumentalist nature of language controversy is expressed in the following quote,

Some ethnic groups, or some communities within some ethnic groups, are saying, "Well, we want to learn in Arabic and not in Tigre or Afar because we spend all our time trading with the Yemenis and the Saudis. We use Afar amongst ourselves, so why do we need to learn Afar anymore?” Well, also for religious reasons: "We want to know Arabic more so that we can study the Koran and so on-but also so we can further ourselves through trade.” (Gottesman 1998: 226).

The instrumentality of this preference is revealed in that the Arabic language is needed to serve as a means of communicating in the market space. Even in connection with religion, it is seen as an instrument of learning Koran. No attempt is made by the interviewed to afford it an intrinsic value. In the quoted paragraph there is no claim of the sort of "it is our language” or "our identity”. Probably this is so that except for a small ethno-linguistic group, the Rashaida, which can rightly claim Arabic as its vernacular language (intrinsic value), the rest refer to its spiritual and communicative significance for them.

Experiences of other societies also provide ample examples of this instrumentalist nature of discourses of languages. In a similar vein, studies done in Nigeria regarding mother tongue and English show that parents prefer English to their own mother tongue as a medium of instruction of their children. The same attitude is expressed in Namibi; 'They told me that these parents had expressed the opinion that schools whose medium of instruction is 
Oshindonga are useless for the future of their children' (Brock-Utne 2000: 201). Brock-Utne (2002: 7) also reports a similar tendency in Tanzania where private primary schools using English as the language of instruction is spreading. Parents whose choice is English argue, 'in a time of globaliszation, English is the language of the global village'. In the Nigerian case this is explained by the parent's belief that since English is the language of the office their children would benefit if they were educated in that language. Similar views are also expressed in South Africa (cf. Webb 2002: 10). English is perceived as a good investment for the future of their children as well as themselves, since children are considered as their parents' life insurance. Most significantly, however, it is presumed that equipped with linguistic capital, their competitive capacity, in the market, increases considerably.

\section{Ethnic Identity and Mother Tongue: Politicization of Language}

This section discusses the correlation between ethnic identity and mother tongue. Moreover, it analyses how the politicization of mother tongue undermines its functional social communicative value. The literature on identity shows a close relation between ethnicity and mother tongue or vernacular language. Mother tongue is perceived as one of the markers of ethnicity. Yet some argue that the relation is not a deterministic one, that is, mother tongue does not determine ethnicity. There are many social groups categorized as ethnically differential but having cognate speech, such as the Tutsi and Hutu, the Croats and Serbs. Nevertheless, vernacular language, wherever it exists, could constitute one of the indispensable ingredients of the formation of ethnic identity. What all this indicates is that the role of mother tongue (vernacular language) in identity formation is ambiguous, contingent upon the situation. In certain circumstances it can be necessary but not sufficient, in others necessary and sufficient, yet in other cases neither necessary nor sufficient (Anderson 1991, Herman 2007: 217). Generally, language is considered as 'a very strong symbol of ethnic identity' (Opeibi 2000: 188). Reaume (2000: 25) also notes, 'Most people value their language not only instrumentally, as a tool, but also intrinsically, as a cultural inheritance and as marker of identity as a participant in the way of life it represents'. He further adds that language is a repository of the traditions and cultural accomplishment of their community. That language is a central feature of identity is also stressed by Stephen May (2001).

No doubt every community perceives its language to be an indispensable part of its culture. Looking down on its language could be seen as disrespecting and undermining its culture, and could lead to violent confrontations. The relation of language to culture could be 
described as that of part to a whole. In other words language is a composite element incorporated in a cluster that constitutes a larger body. The ethnic group's endeavour to preserve its language is intended to protect its culture. Beyond protection it also demands for recognition and equity, which in turn presupposes a shared space where an interplay of exchange, compromise, competition, negation, nihilism, interchange, co-existence, confront one another depending on the strategic, situationality of relations. Here it is possible to state that there is no straightforward measurement that explains the relation between mother tongue and ethnicity or ethnic identity. What is of saliency is that an ethnic group's language is what it deems to be its language, not necessarily a primordial vernacular language (Anderson 1991). This has been clearly demonstrated by the discussion in the previous section.

Generally, it is understood that cultural elements, which include sets of beliefs, patterns of individual and social relationships and networks, and patterns of worldviews are embedded in language. As such, thus, language is perceived as an embodiment of social or ethnic identity that is manifested in and supported by ideological beliefs and movements. As a version of ideology, 'Linguistic nationalism is that version of nationalism which is concerned about the value of its own language, seeks to defend it against other languages, and encourages its use and enrichment' (Mazrui and Mazrui 1998: 5). The absence of such cognitive development is then taken as an indication of the absence or less developed ethnic identity.

The discourse of language in Africa can be discerned at three levels noticeably; 'Most sociolinguistic studies on Africa recognize a three-way distinction between 'vernacular' languages that serve as media of intra-ethnic communication and solidarity, vehicular languages of inter-ethnic communication and integration, and official languages of administration and national communication' (Mazrui and Mazrui 1998: 79). The choices made from these three categories will definitely indicate the predisposition of a group whether it draws the basis of its identity formation from primordialism, constructivism, and instrumentalism. In reality, however, it is a blend of all or some of these, which define and explain ethnic identity formation.

Unlike the orthodox ethnicist approach's claim, which makes a direct correlation between mother tongue and ethnic identity formation, it is not rare that choices are made according to instrumentalist and constructivist perspectives, as we saw in an earlier section. This is expressed in that groups could, entirely on their own free volition, abandon their own mother tongue and subscribe to a supra-ethnic or a transcendent religious language. Here two processes could be observed as taking place. One is a process of constructivism where, 
particularly, a religious language is adopted as one's own and concomitantly a collective identity is constructed. The second is, while recognizing mother tongue, because of instrumental and functional benefits that could be reaped; other languages are preferred for use in the public realm. Here again it could be observed that two processes are taking place. Firstly, a political scheme intended to serve the formation of the imagined or actual 'we and they' dichotomy, which by design aims at creating socio-political equilibrium, take place. This in turn seeks to ensure political, economic and cultural balance, in Bourdieu's terminology equitable allocation of capital. Secondly, a genuine need to identify oneself with a sacred cosmology, mediated through sacred script, constitutes a motive for a preference, 'Sacred scripture is itself an additional fertilizer for linguistic nationalism' (Mazrui and Mazrui 1998: 6). The identity formation under Arabic-Islamic category in Eritrea is a formation of supra-ethnic religious nationalism (cf. Bereketeab 2000: 269f, Bereketeab 2002), partly driven by the ambition to enhance profitability of capital produced and reproduced in the linguistic market. Here it could be observed that the two dimensions are simultaneously employed. On the one hand, driven by instrumentalist motive, the various ethno-linguistic groups that confess Islam are observed selecting a lingua franca (Arabic) that would ensure their competitive advantage vis-à-vis Tigrinya; while, on the other hand, motivated by primordialist or intrinsic value, because of the sacred cosmological value Arabic have for Moslems, Eritrean Moslems select Arabic. The politics of identity as expressed and defined in the Islam-Arabic paradigm necessarily suppresses the ambitions of many ethno-linguistic groups subsumed in it, however. Arabic is serving here as a language of an inter-ethnic communicative and integrative means and mechanism. This represents a case where mother tongue is neither necessary nor sufficient for collective identity formation. One way or the other, language is politicized in order to achieve certain political values, capital.

Nevertheless, in Eritrea, there are ethno-linguistic groups seeking to deconstruct the dichotomization strategy. They oppose the tailoring of two straightjackets that ethno-linguistic groups are forced to fit themselves into. These ethno-linguistic groups include Afar, Blin, Kunama and Tigrinya. The last group's (Tigrinya) case is different from that of the others. As the largest ethno-linguistic group, also as it does not fall in the Islamic-Arabic subsummation, its concern with the dichotomization is of a different nature. It may be that as the intended target of the subsummation, the group's rejection of the dichotomy could be understood as an attempt to escape encirclement by the Islamic-Arabic bloc ${ }^{5}$.

\footnotetext{
${ }^{5}$ The construction of dichotomy: Islam-Arabic and Christian-Tigrinya is believed to emanate from Moslem elites intended to create equilibrium between the two sections. Unless the various ethno-linguistic groups
} 
The objection to the strategy of dichotomy emanates partly from the wish to develop one's mother tongue and partly to eschew subordination. They seek to develop and preserve their languages manifesting what Mazrui and Mazrui (1998) have called 'linguistic nationalism'. This deconstruction also rests on both the primordialist and instrumentalist perspectives. From the instrumentalist perspective the groups are displaying a manifest intention of protecting their interest, in Bourdieu's (1991: 57) expression, saving a market where the values of language competence are maintained and equality is ensured. Conversely, from the primordialist perspective, these groups not only want to preserve their prevalent cultural values, norms and belief systems but also, through employing their language in the private sphere as well as in the public sphere seek to ensure the development of that culture.

Culture is the main pillar in any cultural system, and literacy in a given cultural system represents the most important feature in the development of a capacity for a language to work either as a repository of past knowledge or as a basis for the development and integration of new knowledge into the society or cultural system. In all societies, which are able to advance forward scientifically and technologically, primacy is vested in the development and use of languages indigenous to the people (Prah 2001: 7).

Those demanding the right to mother tongue education have probably in mind what is quoted above. Here we have a situation where mother tongue assumes both necessary and sufficient condition for the formation of ethnic identity. We are witnessing a case where there is a direct correlation between mother tongue and ethnic identity formation.

This is a display of two diverging identity formations in connection with ethnic identity and mother tongue in Eritrea. On the one hand, we have a claim on supra-ethnic identity formation that invokes sacred language as a basis for multi-ethnic identity constellation and is grounded on the instrumentalist and constructivist perspective. On the other, we have ethnic identity formation that rests on mother tongue-culture-ethnicity nexus invocating both primordialism and instrumentalism as the basis of identity rights claim.

If language is perceived serving as a means of communication where it is accorded value-neutrality and as only serving the purpose of interaction between groups then there is possibility for narrowing the gap between opposing claims of identity. This perception would further be enhanced by the fact that many of the ethno-linguistic groups speak at least two

confessing Islam are subsumed under Islam-Arabic they would not be able to match the dominant Tigrinya ethno-linguistic group, is the rationale behind it. The Tigrinyans, therefore, have to oppose the strategy because its primary aim is to dominate them. There are those who believe that among the reasons many Christian were lured to support the cause of union was the fear that a combination of Eritrean Moslems, Arabs, Sudanese and Eritrea's proximity to the Middle East might subject them to domination. 
additional languages to their own. This could be realized if only language assumes discursive communicative property that is appraised merely by transcending the interlocutors' specific values. Yet, the smaller ethno-linguistic groups aim for what Jones (2006: 140) designated as 'reciprocal recognition: everyone should accord recognition to everyone else'.

On the other hand, if it is politicized and assumes intrinsic value, reconciliations and compromises between language rights claims become extremely difficult. The ethnic and linguistic discourse among Eritreans and especially at an elite level, since the 1940s were marked by either bipolar (Christian-Tigrinya and Islamic-Arabic) (cf. Negash 1999: 60, Tesfai 2005: 170) or multi-polar (ethno-linguistic rivalry) disposition. This disposition is driven by political elite rivalry and politicization of language aiming at conquering the state where the state is perceived as a market where the linguistic capital is produced. The rivalry first manifested itself in the 1950s between the Moslem League elites, on the one hand, and the Unionist elites on the other. Later, during the liberation struggle, also a variance of language policy was displayed between the ELF and EPLF leaders (cf. Negash 1999: 56-60, Bereketeab 2004: 224). That prospect seems to have the effect of pitching the various elite groups, claiming to represent their respective ethno-linguistic groups (multi-polarity), and dichotomy (bipolarity), one against the other.

To sum up, the strife for the ascendency to political power leads to the need for mobilization and organization of resources among which ethnic resources are involved. Language as a symbolic power resource is not only mobilized but also politicized divested of its instrumentalist communicational value, thereby, assuming an essentialist value. In its essentialist, deterministic and defining property of ethnic identity, and in its competitive performative political role, language has assumed, in the Eritrean setting, what Bourdieu has called linguistic market where individuals seek to maintain or alter the distribution of the forms of capital reflecting their specific profitability to them. This has led to active construction and reconstruction, and to the politics of rights where some ethnic and religious groups, and even sub-ethnic groups, are making efforts to elicit reciprocal recognition.

\section{Mother Tongue Education vs. Democratic Rights Argument}

This section discusses the increasingly growing influential argument that postulates educating children in their mother tongue not only is necessary for their development but also is a fundamental aspect of democratic rights. It is often argued by the 'rights orientation' strand, “the language as right 'orientation' considers language as basic human rights, and that 
every human being has the right to choose a language” (Agbedor 2009: 141). The politics of language in Eritrea is also geared along the democratic rights argument. The democratic rights argument, particularly of the child, seems to be pursued, primarily, by the government. The credibility of the argument is, however, contestable. The Eritrean Government's education policy has its roots in the EPLF's vision of education during the time of the liberation struggle (cf. Gottesman 1998, Negash 1999). That vision was incorporated in the ratified Eritrean constitution. Article 4: 3 of the Eritrean constitution states, 'The equality of all Eritrean languages is guaranteed'. Unlike rival organizations that focused on official languages Arabic and Tigrinya - the EPLF from very early advocated the equality of languages and the use of mother tongue as a medium of instruction in education. The argument of the right to develop ones mother tongue was intimately connected with democratic rights. The current education system, at the basic level, is divided into three levels, namely elementary (1-5), middle (6-7), and secondary (8-11) (MOE 1998) ${ }^{6}$. Whereas at the elementary level, the medium of instruction is the mother tongue, at the middle and secondary levels it is English (MOE 1999). While Tigrinya is taught as a subject at the elementary level, Arabic is taught at both elementary and secondary levels. The medium of instruction for tertiary education is English. According to the government instruction of children in mother tongue has given a positive outcome in the overall performance of school children. International studies also uphold such assertion.

Yet the introduction of mother tongue as a medium of instruction has generated considerable controversy (Hailemariam 1999: 488, Bereketeab 2004: 219-20). The controversy include claims such as teaching mother tongue weakens the position of the Arabic language, and that mother tongue education in nine languages is impractical, since this would mean mobilizing huge material and human resources (Negash 1999, AbaArre 2001). The concern of communities may focus on the democratic rights of any community to promote and develop its identity and culture in which mother tongue is embedded. As Reaume (2000: 271) argues, 'People find in their mother tongue a marker of identity, an expression of their belonging to a community, a unique and valuable form of human creativity'. As such not only from an instrumental but also from an intrinsic value point of view, they seek its preservation. Yet no uniformity could be claimed, as was discussed earlier; communities may prefer a medium of instruction other than their own mother tongue. Les Gottesman's studies in Eritrea

\footnotetext{
${ }^{6}$ Since the school year $2003-2004$ secondary school years has been raised by a year to $12^{\text {th }}$ grade. Those who complete their $11^{\text {th }}$ grade education have to attend a year of study $\left(12^{\text {th }}\right.$ grade $)$ at the Sawa Military Institute. The official explanation why they are forced to complete $12^{\text {th }}$ grade at a military institute is that because of the availability of necessary facilities.
} 
show some communities expressed preference of different medium of instruction than their own mother tongue.

Sometimes instead of using their mother tongue, in some areas they prefer some other language, they prefer Tigrinya, or they prefer Arabic because they think that since these two languages are more widely used in many parts of Eritrea and everybody knows this language so our children could benefit more from this, and so on (Gottesman 1998: 226)

Here, parents are aiming, by choosing a language they perceived is more marketable than their own, at the linguistic market where competitive and profitable legitimate linguistic competence is earned. What becomes appealing is that adopting the language of formality or office in which mastering it may lead to a prestigious and profitable job in the public sphere. If it is another language than one's own then let it be.

Many post-colonial African governments introduced mother tongue instruction, at least, at lower levels. For instance, Uganda, Guinea (between 1968 and 1984), Botswana, and Somalia shifted after independence to mother tongue instruction. Niger is in the process of introducing a new policy of mother tongue as a medium of instruction in education. After independence Namibia granted ten vernacular languages the status of medium of instruction in functional literacy and in three lower primary grades (Brock-Utne 2000: 192). Yet so far, the debate on mother tongue education is, overall, to say the least inconclusive. In some countries it has generated heated and divisive debates (cf. Cohen 2006).

In all the controversy, however, one compelling argument is that mother tongue education is an element of fundamental democratic (or human) rights. Indeed, there are those who see it as a prerequisite for the development of the community (cf. Tesfai 2000, Thiong'o 2000: 17, Brock-Utne 2000, Gottesman 1998). It is perceived, in other words, as a community's basic democratic right to use and develop its own language. Furthermore, those who uphold the democratic rights view refer to international laws and conventions that emphasize people’s rights as basic human rights. The World Declaration on Education for All (WDEFA), concerning education through mother tongue notes, 'Literacy in the mother tongue strengthens cultural identity and heritage' (WCEFA, 1990: Article 5, quoted in Brock-Utne 2000: 149). But most significantly, the appreciation of mother tongue education is seen in the realm of development, as Echu (1999: 24) citing Chumbow stresses that 'the early use of the mother tongue in education has significant long term benefits with respect to maximizing the development of the intellectual potential of the child'. He further argues that mother tongue 
education should be introduced in the early years of primary education, and official language should be introduced later on (Echu 1999: 25). One of the advantages of learning in ones mother tongue, it is presumed, is that children use the same language both at home and in school. This would certainly not only make education easy but also quicker.

Since it is through the mother languages that infants first acquire social habits, manners, feelings, tastes, skill, and other cultural norms, it is important that their formal schooling starts with those languages of everyday life at home, (SWAPO, 1989: 6, quoted in Brock-Utne 2000: 189)

The Eritrean Government's argument is that basic education in the mother tongue is a fundamental democratic right, as well as it is of vital importance in harnessing the development of the child. This view may be informed by the liberal democratic theory that perceives protection of languages as inherent right (Laitin 2007: 117). In my discussion with officials of the Ministry of Education (MOE), in April 2000, I found out that opposition of parents to mother tongue instruction is simply shunned away on the ground that it fails to put the child's interest at the centre. Gottesman's (1998: 226f) interviews with officials of the MOE also express similar views.

The proponents of the view of basic education in mother tongue uphold that parents' preference for Arabic should be juxtaposed with the rights of the child. Here it is passionately argued that the child's right should be given priority. The issue of the child's rights raises, however, a legitimate question of who has the right of taking the decision-the parents or the state. The parent versus the state, in relation to the right to decide the child's medium of instruction, is also related to ethnicity versus state. The liberalist view would argue that the individual child should be able to choose, not simply follow his parents' choice (Laitin 2007: 122). This concern prompted me to raise a question in our discussion with officials in the MOE about what should come first - ethnic rights or the right of the state to impose educational policies and medium of instruction. The answer given was that state policies should be afforded precedence over parents' wishes. The question becomes even more complicated when it is posed in the manner of ethnic versus state. If the protagonist was the isolated individual or parents opposing the state, it would perhaps be easier for the state to overlook the wish of parents. But when the ethnic group as a collectivity substitutes parents, the matter then assumes a complex political dilemma. This is so that a majority or stronger ethnic group in power may override the wishes of minority groups and may impose its own language preference. 
Moreover, when mother tongue is juxtaposed against democratic rights, the fundamental question that comes to mind is democratic rights of the individual or the collectivity-ethno-linguistic group. This brings us to the perennial debate between liberal theory and communitarian theory (cf. Kymlicka 1995). Kymlicka (1995: 34), after saying that there is no contradiction between liberalism and collective rights, maintains that individual rights of minority groups could only be achieved within collective rights. We will not now indulge in the philosophical debate whether individual rights or collective rights take precedence, or if they are mutually exclusive or not. What is of interest is that, in Eritrea, both proponents and opponents of mother tongue education seem to take ambivalent position concerning this question. If we take, for instance, the view of the proponents of the mother tongue education the whole argument is built on the development of the ethno-linguistic group. Yet, it does not appear that the ethno-linguistic groups are given the full opportunity to choose, plan, execute and monitor the development of the language of their choice. Quite often the decision comes from above, a top-down strategy, exercised by the government and elites of organizations. What is conspicuously missing is bottom-up strategy where the communities are allowed room to make their own decisions. Perhaps the reluctance to let the ethno-linguistic groups decide for themselves could be explained by the fact that what is desired is not the consolidation of ethnic identity, but national identity. In that sense ethnicity is perceived as transitory phenomenon, an ephemeral stage, until the desired goal is achieved. Hence mother tongue should not be used to enhance ethnicity as cemented identity formation. As Mazrui and Mazrui (1998: 103) note the sociolinguistic consequence of mother tongue education in polyethnic society could be vertical integration at the expense of horizontal integration where ethno-linguistic affiliation and solidarity grows stronger that cross ethnic and geographical integration is impeded. This is exactly what nation builders are afraid of.

Neither are opponents of the mother tongue education concerned about the democratic rights of the individual or the ethno-linguistic group when it comes to the language issue. Their main concern is the position of the Arabic language in society. They think the introduction of mother tongue education would discriminate Arabic by disintegrating the Moslem communities, since learning mother tongue substitutes Arabic. They accuse the government of dismantling Arabic schools and substituting them with mother tongue schools (cf. AbaArre 2001, EISM 1998: 3). Moreover, mother tongue education policy is probably evaluated from the effect it would have on the undesired consolidation of ethnic identity, since the aspiration is supra-ethnic pan-Islamic identity (cf. Bereketeab 2002, 2004). 
Paradoxically, both groups seem to be in confluence in their implicit or explicit opposition to ethnicization.

\section{Official Language Versus Equality of Languages (Mother Tongues)}

This section focuses on the debate revolving around the policy of adopting official language versus endowing mother tongues equal status. A linguistic community can be defined as a group of people who use the same system of linguistic signs (Bourdieu 1991: 45). Most societies consist of multi-ethnic communities speaking various related or unrelated languages. In the absence of a single major language commanding loyalty and adherence across community boundaries there arises a competitive relation among the languages. The need for modern states to centralize and integrate their citizens on one hand, and to distinguish themselves from others, on the other, made it necessary to have some kind of formal language that serves in the public sphere. In this sense official language is endowed a high political and symbolic value connoting sovereignty of the state. The choice and process of evolvement of this formal official language pursued a variety of routes (more on this later).

Scholars are divided concerning the status of languages. Some champion the equality of languages, 'Every language, whether spoken by a community of only a hundred or by a community of millions has a right to be and a right to develop a literature and knowledge unhindered by the policies of the State. The acceptance of the unqualified equality of all the nationalities within any one country and in Africa as a whole is the prerequisite for any success of a national or even a continental language policy' (Thiongo'o 2000: 16-17). This is, however, an extreme view of language rights. Nevertheless, in spite of the increasingly growing disposition of using mother tongue as medium of instruction only few governments have or had policies of mother tongue education. Guinea had an official mother tongue education policy from 1968-1984 whereas in Uganda it still is an official policy (Brock-Utne 2000: 166). The juxtaposition of mother tongue and official language in a polyglotic and polyethnic societal setting may take a special fashion of arrangement. In these types of societies rarely does the condition exist where the official language is congruent with mother tongue. In the absence of such congruence their relation assumes a hierarchical order where official language serves the formal and public sphere (national polity), while mother tongue may serve the informal and private sphere (local level) of the polity. 
Among Eritreans the debate on official language and mother tongue engenders heated debate and has become a very divisive matter ${ }^{7}$. One of the reasons that make it so emotionally charged and complex is that mother tongue and official language are put in a zero-sum state of relation. One way of easing this tension would then be making functional and structural distinction between mother tongue and official language.

The debate on official language versus non-official language in Eritrea reflects the unresolved and confused nature of relation between official language and mother tongue. Proponents and opponents of either strand of the binary, supported by a variety of validating and legitimating arguments and analyses, passionately argue that endorsing their preference of the binary is in the best interest of the nation. Proponents of official language, for instance, as a support for their argument, invoke that Arabic and Tigrinya served as official languages in the past (cf. Gottesman 1998: 80), and in that capacity they (the two languages) symbolized and affirmed Eritrean national unity. Failing to adopt official language policy, its proponents maintain, would certainly lead to division of society. According to their assumption, Arabic and Tigrinya would ensure cohesion of society consisting of two socio-cultural formations. For opponents of bilingual official languages policy, conversely, Tigrinya and Arabic were introduced as official by colonial powers, as colonial project therefore had to be corrected in the post-liberation state arrangement (Negash 1999: 56).

Proponents of official language argued that equality of languages will create serious practical problems such as providing adequate teaching staff and material for mother tongue schools. It would be economically expensive to provide necessary provisions-translation facilities_-in the public sphere in all nine languages (Negash 1999: 54-5). They also argue that it will lead to isolationism (Ahmed 1996). The issue of expenses, although casting light on the problem of practicability, is very technical. It has to be weighed against the issue of principle that is the communities' rights for their own mother tongues according to an official of the Ministry of Education ${ }^{8}$. The politicized nature of the debate is, however, creating an obstacle for a substance-based analyses. So far sensible and sombre discourse of language has proved to be futile. There seems to be a pervasive suspicion that the rationale behind each

\footnotetext{
${ }^{7}$ Inside the country, public debate took place during the drafting of the constitution. Since the ratification of the constitution, however, debate has been running outside the country within the Eritrean Diaspora. The Moslem communities in the Diaspora have been expressing their strong disapproval of the non-official language policy of the Eritrean government. Not only Islamic movements but also secular opposition groups based in the Diaspora (see political programme of these opposition groups) are also advocating for the bi-language official policy. Various Eritrean Diaspora websites host highly emotional and divisive debates related to language issue. A few that could be mentioned include awate.com, asmarino.com, alkhalas.org, alnahda.com, togoruba.org, islaher.org, omaal.org, etc.

${ }^{8}$ Interview with an official of the Ministry of Education, Asmara, 2000
} 
strand's stand is the urge for socio-cultural and political domination. The suspicion further gains currency because the discourse is carried out primarily by opposing political forces who might have their own political agenda. Academic research is markedly absent.

For the Government, the language issue is constitutionally resolved through constitutionally affording all languages equality. The policy of non-official language is intended to ensure equality of mother tongues (cf. National Charter 1994, Constitution 1997). Opponents of the government, however, charge that the non-official language policy is creating domination of the Tigrinya mother tongue and consequently endangering unity of the nation.

The language issue remains a critical one still plaguing many societies. It was not only post-liberation Eritrea that sought to address the issue of language through adopting policy of equality of mother tongues. The post-apartheid South African Constitution also made all eleven major languages equal and official (see Brock-Utne 2002: 11). Nevertheless, in spite of equality of languages, Afrikaans and English are still privileged in South Africa (Brock-Utne 2002: 12), as Tigrinya and Arabic are dominant in Eritrea. In practice Arabic, English and Tigrinya are serving as working languages in Eritrea (cf. Handbook 2002:36, Hailemariam 1999: 486). This should have assuaged fears of proponents of official language policy. Yet, since in virtue of its demographic preponderance, Tigrinya has gradually assumed undeclared official status, the fear of the proponents of official language policy seem to have been realized and consequently the resentment of non-Tigrinya groups on the Tigrinyans has been greatly reinforced.

The acrimonious debate revolving around the relation between mother tongue and official language in Eritrea seems partly to stem from an erroneous zero-sum perception that is supposed to guide the relation. To tackle this problem, we could suggest therefore, above all, the zero-sum perception has to be rejected. Any view that upholds the perception that adopting the one is a guaranteed loss of the other should be rejected outright. Secondly, if at the end a policy of official language is adopted, a distinction needs to be made. As it seems to be the case, if Arabic and Tigrinya are selected as official languages, it should be acknowledged that they preoccupy formal and public sphere position while the rest of the mother tongues may occupy the informal, private or sub-national positions. In this respect there would not be a winner or loser - zero-sum - relation because the other ethno-linguistic groups are also given the chance to develop their vernacular tongue.

The distinction made between mother tongue and official language might probably contribute to the easing of the polarized debate on the language issue. From the discussion 
above it might safely be concluded that the fear based on the zero-sum perception that rights for mother tongue would mean loss for the Arabic language and vice versa does not appear to hold ground. The project of packaging the various ethno-linguistic groups into a pan-Islamic identity cluster, with the intended aim of creating social equilibrium, probably, also need to be avoided. It is repressive seen against mother tongues, but also creates an artificial bipolar Arabic-Islamic and Tigrinya-Christian - that might have a corrosive effect on social cohesion. Because, for sure, it also evokes a feeling of suspicion among Tigrinya speakers about the intention of pan-Islamic agents.

It would be worthwhile to point out that Arabic and Tigrinya are both lingua franca and vernacular languages ${ }^{9}$. Arabic is a vernacular language because it is a mother tongue of the Rashaida ethno-linguistic group. It is also a lingua franca because it is used across the various Moslem ethno-linguistic communities as a medium of communication as well as language of the Holy Book, Koran. Similarly Tigrinya is a vernacular language because it belongs to the Tigrinya ethno-linguistic group, and it is also a lingua franca serving as a means of communication across various ethno-linguistic groups.

\section{Why Bilingual Official Language Policy?}

This section analyzes the rationale behind bilingual official language policy in Eritrea. It argues that, if official language policy is endorsed, then it could only be bilingual; the reasons for this are also detailed. There are strong arguments for the benefits that can be harvested from having a single official language. The parsimoniality of having a single official language in terms of economics, politics, social, culture, and technology is often emphasized. (Reaume 2000: 269) notes, 'It is obviously much more convenient and costeffective if everyone in a country speaks the same language'. Opponents of mother tongue in Eritrea also alluded to the cost incurred in having a policy of equality of mother tongues (Negash 1999: 54-5). Further, what speaks for this perspective is the presumption that monolingualism contributes to national unity. The precarious nature of the societal formation of developing societies is often perceived as rendering these societies vulnerable to linguistic division and claims thus lending currency for the choice of mono-linguality.

\footnotetext{
${ }^{9}$ From technical and instrumentalist perspective are languages described as lingua franca when they are used as means of communication across boundaries of ethno-linguistic groups, while simultaneously they constitute vernacular languages due to their intrinsic value to certain ethno-linguistic group(s). This reality however would not diminish the symbolic political meaning and role, particularly when language is politicized, in a polyglotic and polyethnic societal setting.
} 
The functionalist school of thought, unlike the formalist one, 'see language as a system of human communication, an instrument of verbal interaction among human beings ...an instrument by means of which people can enter into communicative relations with one another' (Opeibi 2000: 187). Moreover, communication is defined as 'the ways we transmit our thoughts and feelings to other people either by speaking or by writing and receive other peoples' thoughts and feelings either by listening or reading' (Opeibi 2000: 187). According to the functionalist approach what matters is that people are communicating rather than whose language is being used.

Nevertheless, communicative needs are not the only reasons governing language preferences. As the formalist school of thought (see Opeibi 2000: 187) demonstrates language is also imparted in its own value. Arguing along this line Reaume (2000) makes distinction between the instrumental and intrinsic value of language. In the intrinsic value perspective, linguistic value is shifted, from a rational calculative to a position of endowing language a reified status, good in itself (Reaume 2000: 246). Both intrinsic and instrumentalist perceptions of language have implications for the preference of official language, in this case bilingual official language.

Socio-cultural realities that form a congenial base for an ideal situation where monolingualism is the modus vivendi are, however, rarely readily available in post-colonial societies. This is particularly true when we pay attention to the fact that African nations are the product of colonial mishmash, that is, encompassing multifaceted polyglotic and polyethnic entities. The societal formation of the Eritrean society necessitates addressing the issue of official language in a manner that satisfies both intrinsic and instrumental values of the various ethno-linguistic groups. In that sense the issue of bilingual official language has occupied a central position in the Eritrean polity since colonial times in the 1940s. It assumed a centre stage when the British authorities and the UN embarked on drafting the constitution of the autonomous Eritrean state. Indeed, it is widely believed that it was the British authorities, deriving from their conviction that Eritrea consists of binary socio-cultural units that formalized the notion of bilingualism (Young 2008: 17, Bereketeab 2004: 222). Since then the notion of bilingual official language has characterized the socio-cultural and political discourse in Eritrea.

The ideal situation for Eritrea would be a single official language model. This would certainly have facilitated the nation state building process. From a utilitarian perspective it is wise and politically motivated to search for a widely used lingua franca. At a certain point of time, prominent Nigerian academics and politicians advocated for the choice of Hausa as a 
Nigerian lingua franca. It was rejected on the ground of political and cultural implications (Opeibi 2000: 193). In the case of Eritrea, although, as far as my knowledge goes, there is no statistical data, the estimation is that more than 80 percent of the Eritrean society may be able to communicate through Tigrinya. Therefore, from a communicative instrumentality and functionality point of view a compelling argument could be done for Tigrinya to be an official language. This argument would assume currency when taken into consideration that a language with communicative power of only 35 percent (Ivory Coast), 20 percent (Kenya), 10 percent (Namibia), 30 percent (Nigeria), 5 percent (Tanzania) (Webb 2002: 6) could be the official language.

Yet, politically, it could not be accepted as a sole official language (cf. Negash 1999, AbaArre 2001). This is because it is associated with an ethno-religious group. Indeed Moslems see it as a language of the Christians representing and reflecting their values, norms and belief system. In other words it is given an intrinsic value instead of assuming instrumental functional value. Conversely, there is a large group who can communicate through Arabic. Neither could Arabic be accepted as a sole official language, for two reasons. First, it is only a tiny minority group (the Rashaida) who could rightly claim it as its mother tongue. Second, it is associated with a religion - Islam - and might not be acceptable to the Christians. It is widely believed, in socio-linguistic studies, that the successful elevation of a language to the position of lingua franca is contingent on it not being affiliated with a particular ethnic or religious group (see Mazrui and Mazrui 1998: 180). Such affiliation of a language with an ethnic or religious group makes it less appealing to the other groups to be a lingua franca because they think it would lead to their domination. In addition what makes the language issue in Eritrea very critical is its politicization.

This politicization of language was further complicated by the emergence of two rival organisations during the liberation struggle: the Eritrean Liberation Front (ELF) and Eritrean People's Liberation Front (EPLF). Broadly speaking, the leadership of the fronts exhibited variance in their language ideologies (Negash 1999: 56-60). But most crucially, they were perceived as representing binary socio-cultural identity formations. The ELF leadership was perceived as, more or less, inclining toward Arabic-Islamic socio-cultural identity, whereas the EPLF leadership was perceived as inclining toward Tigrinya-Christian socio-cultural identity. This feeling was primarily fostered by many Moslem leaders of the ELF (cf. Amar 1992: 104, 106, Bereketeab 2004: 220, Negash 1999: 56-60, ELF-RC 1989).

Arabic is also considered by the Christians as embodying Islamic values, norms and belief system. If either language is, then, to have a chance of becoming an official language it 
has to shed down its intrinsic value and assume instrumental value. Unless they are deconstructed from their intrinsic value, or their functional and instrumental value - as means of communication and interaction - is imparted pre-eminence, separately, they are going to be invariably dysfunctional. Their social functionality could only be conceived under the circumstance that they both ascend to officialdom. Both languages could only function as official languages by providing an alibi to each other. In this sense there seem to exist a sort of imperative political symbiosis between the two languages. Hence some sort of structural arrangement is required in order for them to be functional in their designated roles as social and symbolic national icons.

In a situation where bilingual official language model reigns, if they are not deconstructed of their intrinsic value, the social consequence could be a development where a bi-nation (two nations) model becomes predominant. This is so because as the formalismintrinsic perception demonstrates by endowing language its own value, and further in a normatively prescribing language to be a fundamental component of culture, and by extension, by imparting culture the chief defining as well as determining criterion of an ethnic nation or ethnonationalism, it paves the way, at least in theory, for the creation of two nations; although the call for bilingual official language policy aspires to engender fluent bilingual Eritreans. This scenario resembles the critical ethno-linguistic based ethno-nation formation plaguing countries such as Canada, Belgium, Switzerland described by Will Kymlicka (2006: 57). The sociological down side of the bilingual official language policy and its probable resultant bi-nation formation is the danger it poses in the division and ultimate creation of two sovereign nation states. It is also discriminatory, that is, it discriminates those ethno-linguistic groups that oppose falling in the straightjacket binary. It would relegate the minority groups that do not fall in the binary to subordinate position. Bourdieu (1991: 6) observes,

By promoting the official language to the status of the national language-that is, the official language of the emerging nation-state-the policy of linguistic unification would favour those who already possessed the official language as part of this linguistic competence, while those who knew only a local dialect would become part of a political and linguistic unit which their traditional competence was subordinate and devalued.

Further it might also, as some fear, have the effect of, 'the fact that the religious/regional cleavages divide the Eritrean society into two equal and unranked groups (Horowitz 1985, 23-26), which when politiciszed and mobilized could polarize the society 
into two large warring religious/regional proto-national groups and destabilize the very foundation of Eritrean claims to self-determination and independent statehood' (Woldemikael 1993: 197). Perceived from nation formation perspective, then, a bilingual official language strategy runs the risk of producing two mutually exclusive nations that is worrisome and disruptive to the nation state building agents. It is this phenomenon that is pushing Belgium to the brink of division into French speaking and Dutch speaking (cf. Kymlicka 1995, 2006).

In Mazrui and Mazrui’s (1998) typology of African languages, Tigrinya would fit in the Afro-ethnic languages category and Arabic in the Afro-Islamic languages category ${ }^{10}$. The African origin (sub-Saharan) of Arabic, in the Eritrean context, however, is quite often put into question. The Unionists, for instance, exerted stiff resistance before accepting Arabic as the co-official language in the 1950s for the sake of national unity (cf. Bereketeab 2004: 2223, Tesfai 2005: 170). Their argument was that Arabic is an alien language. Since the 1950s, when the UN-sponsored federal arrangement introduced a bilingual official language, competition and functional complimentarity seem to characterize the two languages, at the public sphere, in Eritrea, however.

\section{Official Language: Social Integration and Nation State Building}

Historically, the emergence of official language and the evolution of the modern state went hand in hand. In Europe, the transition from the absolute monarchic state to the modern liberal capitalist state was accompanied by the struggle to develop an official language. Indeed as Stein Rokkan (1975) observes the emergence of vernacular languages in opposition to the Greco-Latin language advanced the formation of modern nation states. This ontological overlap gradually informed the epistemic genre of all subsequent actors of nation state building where replication was taken as necessary measure to ensure potent and functional nation states. Until the French Revolution the thrust of official language was instrumentally connected with construction of monarchical state (Bourdieu 1991: 46). Yet environmentally,

\footnotetext{
${ }^{10}$ The Afro-ethnic category entails all the languages whose speakers are primarily African and which have been shaped minimally, if at all, by Arab-Islamic or Euro-Christian impact. Afro-Islamic languages are native to Africa in terms to their speakers. Unlike Afro-ethnic languages, the Afro-Islamic language have been influenced heavily by Islam due to the identity of their native speakers over centuries and contact with the Arabic-Islamic world (Mazrui and Mazrui 1998: 70).
} 
as a high culture (Gellner 1983), it was hanging high up at the nobility, upper class level. It was only pursuant to the French Revolution that it was brought down to serve the entire society - upper and lower classes. The French Revolution declared that the nation is equal to the sovereign people (Smith 1983: 191). The emerging modern nation state desperately needed a standardized and centralized official language that imposed its dominance over local dialects (Bourdieu 1991: 46-7). In its endeavour of creating a territorially based national identity, inwardly inclusive and outwardly exclusive, the state imposed a formal official language aiming at homogenizing and centralizing the society within its borders. The rationale behind having official language was that it was firmly believed it would play a catalystic social function in bringing integration and cohesion of society, decisive ingredient in nation state building (Kymlicka and Patten 2003).

This process led, gradually, to the emergence of overall mono-language nation states. Afterwards the principle became an overriding model. Those few that constitute the exceptions like Canada, Belgium and Switzerland found themselves in a state of continuous struggle where centrifugal forces are consistently challenging the central state that made these states to see the mono-lingual state with an envying eye. In the nationalist discourse it is widely held that 'a common language could help create a sense of national identity' (Anderson 1991, Hobsbawm 1990). Fostering linguistic commonality will be conducive to political stability and a greater willingness of citizens to bear the reciprocal sacrifices necessary for the common good' (Reaume 2000: 269) became the predominant perception guiding nation state builders.

In spite of certain similarities, regarding its ontological and epistemological origin, there is a marked difference in the historical route of nation state formation in Western Europe and Africa. The European model was characterized by societal transformation from heterogeneity of imperial states to homogeneity of unique nation states. The African model is often described as a development from homogeneity to heterogeneity. As cogently described by Lewis (1983: 73):

It is a remarkable irony that the European powers who partitioned Africa in the late $19^{\text {th }}$ century when the idea of the nation-state was paramount, should have created in Africa a whole series of Habsburg-style states, comprising a medley of peoples and ethnic groups lumped together within frontiers which paid no respect to traditional contours.

The ambitions and dreams of post-colonial African leaders have been and are still to achieve homogenous nation states. The reality on the ground speaks a different language, 
however. The post-colonial societies of Africa, conscious of the polyethnic and polyglotic nature of their societies opted for the adoption of the language of their colonizers as lingua franca. Awakening African languages is considered as provoking and inciting rivalry and conflict that could certainly lead to the end of African State, as we know it today. Yet, as the work of Mazrui and Mazrui (1998) shows, the absence of linguistic nationalism adversely affects the nation state building process. Indeed, the post-colonial Africa's preference of colonial languages as official language could be considered as regression to the Middle Ages period of Europe where official language was confined to the nobility (a high culture - to use Ernest Gellner's terminology), whereas the general population was speaking various mother tongues (low culture). Hence, instead of bringing together the elite and the masses into a common language, the result has become the prevalence of two sections living worlds apart thereby making the nation state building enterprise precarious and permeated with all sorts of pathologies. The permeability of the nation state building process with all sorts of pathologies has necessarily disposed not only the precariousness of the nation state in Africa but also the divergence of discourse surrounding it.

Official language in its socio-political role, and a contributing factor in nation building is meant to fulfil a vital national role - national integration. Integration as a functional social mechanism in a poly-ethnic setting may take two indispensable forms - horizontal and vertical. While vertical integration involves the integration of the lower and upper strata of an ethnic community, horizontal integration refers to social cohesion across ethnic communities. Further vertical integration also facilitates social communication between the rulers and the ruled (Mazrui and Mazrui 1998: 184) that as was pointed out seem to live worlds apart. In terms of horizontal integration, in the African context where the characterizing feature is poly-ethnicity, integration becomes an indispensable endeavour whose successfulness determines the destiny of the African State. In this integrative function, official language is presumed to play a pivotal role, among other things, through standardized dissemination of information across the nation (cf. Anderson 1991, Hobsbawm 1990).

To turn to the case at hand, the EPLF and later the Eritrean Government, described their education and language policy as intended to promote national unity and development (cf. National Charter 1994, Constitution 1997). As any emerging state, the Eritrean state agents' hope and their ambition, as demonstrated in the various documents (National Charter, Macro-policy, Constitution), therefore, is to be able to build an integrated and unified nation state. National unity and nation state building is one of the declared cardinal objectives of the Eritrea state actors (cf. Macro-policy 1994, National Charter 1994, Ministry of Information 
2002). Nevertheless, the language policy of the GoE goes, implicitly and explicitly, against the tradition of agents of state building where they struggled to achieve a unifying homogenous official language. Indeed, in the first glimpse the policy of language could be seen as a departure from the dominant trend. Though, in reality the development seems to be inclining to single language domination. Overall, the current debate in Eritrea, far from leading to a standardized and centralized official language, believed to be a prerequisite for building cohesive nation state, is geared toward multilinguisticity.

As we could deduce from the analysis above, neither the bilingual official language nor the non-official language-equality of languages_-views in Eritrea, derives from the orthodox monolingual official language principle. Therefore, the implication of both views for the process of nation state building is not clear-cut. Theoretically, both fall short of the commonly understood role and position of the historically unifying and centralizing official language. Empirically, except that it may satisfy those who advocate language rights, it fails to provide concrete mechanisms of how to resolve the problematic that relate multilinguality and nation state building.

The all languages equal, non-official language policy pursued by GoE, contrary to its ambition of building a cohesive, potent and functional unitary nation state, falls short of providing a language policy that would ensure the proclaimed aim. If fully developed it could lead to the emergence of nine language-based nations. Hence, the all languages equal policy, seen from the perspective of the traditional unifying and integrating official language position, is questioned whether it would contribute to the process of nation state building. Neither is the bilingual official language strategy deemed to be friction free, in the way its proponents perceive it. It is likely that it could lead to the development of two nations. These two nations could be based on the two socio-cultural identity formation, notably Tigrinya-Christian and Arabic-Islamic. Experiences of Canada (Quebec) and Belgium are highly illustrative here. Canada seems to increasingly grow into two ethno-linguistic nations - English speaking and French speaking. The problem is more critical in Belgium where the emergence of Flemish speaking and French speaking ethnonations seems to be inevitable (cf. Kymlicka 1995, 2006).

From technical, pragmatic and economic point of view, the bilingual official language policy seems to be more practical compared to a nine language policy. The most unenviable scenario with regard to nation state building, however, would be adopting a monolingual official language. It is important to note that those opposing the language policy of the GoE charge that it is an intentionally orchestrated strategy of Tigrinya political elite to promote the dominant position of Tigrinya (cf. EISM 1998, AbeArre 2001, Negash 1999). This charge 
indicates the politicization of language because it is based on the assumption that the GoE is dominated by the Tigrinya speakers; it never attempts to consider whatever merits the policy might bear. If the charge is correct it may be politically dangerous but instrumentally functional.

One of the problems nation state building and social integration suffers is the marked absence of clear policies, strategies, perspectives, definitions and concepts of language and language policies that are applicable to particular realities and contexts. The implication of this ambiguity of concepts, principles, policies and strategies in the endeavour of nation state building, for the newly born nation state of Eritrea, is thus not unequivocally clear thus the nation state building enterprise and social integration visibly encounters considerable difficulties. The most impeding factor however is the disunity of elites along ethnicity and religion. As long as elites are divided along the Arabic-Islam and Tigrinya-Christian, the nation state building process and social integration in Eritrea will face veritable obstacles.

\section{Concluding Remarks}

I set out in this paper to analyze the politics of language in Eritrea. The analysis identified a number of empirical dimensions around which the focus is centred. These are: (i) correlation between mother tongue and ethnicity, (ii) the right to be instructed in one's own mother tongue, (iii) official language vs. mother tongue, (iv) the imperatives of bilingual official langue, (v) official language and nation state building. All this was preceded by brief theoretical and historical overviews.

The section on ethnic and mother tongue discussed the relation between mother tongue and ethnic identity formation. The paper has demonstrated that the correlation between mother tongue and ethnic identity formation is inconclusive; sometimes it could be necessary but not sufficient, while at another time it could be necessary and sufficient, while yet, at other times, could neither be necessary nor sufficient for the emergence of ethnic identity. It also became clear that the politicization of language sets the relation of mother tongue and ethnic identity, particularly when it comes to instruction in mother tongue, on an antagonistic footing. This antagonistic standing has thus infected instruction in mother tongue while some argue for the right of instruction in mother tongue others oppose mother tongue instruction on the basis that it will undermine the position of Arabic in Eritrea.

The paper also briefly analyzed the evolution and role of official language in Eritrea. In that connection an attempt was made to shed light on the controversy surrounding the 
relation between official language and mother tongue in polyglotic Eritrea. The paper argued that the primary cause of the controversy has to do, partly, with the elites' inability to separate between official language as the formal and official (national public sphere), and mother tongue as in-official, sub-national and local. The controversy, partly, has also to do with power relation among elites. It is argued that the ambiguous relation between mother tongue and ethnic identity is then arguably dictated by the two factors. The paper also highlighted the argument that accentuates that to be instructed in one's own mother tongue, in addition to facilitating the child's development is also fundamental democratic rights of communities as well as individuals. After discussing the benefits and downsides of adopting official language, the paper addressed the imperatives of having bilingual official language in Eritrea. Moreover, the function and significance of official language for the enterprise of nation state building in a historical context and for the post-liberation state of Eritrea is also highlighted. From the perspective of social cohesion and integration, it is argued that official language that stretches across ethnic boundaries (lingua franca) could play a decisive role in the process of building a potent and functional nation state in Eritrea.

The paper has demonstrated that the language issue in Eritrea is so divisive because it involves power relations. After all as Bourdieu suggests language is not only a medium of communication, but also a source of political, economic and cultural power. Further Bourdieu (1991: 66) notes, "utterance are not ...signs to be understood and deciphered, they are also signs of wealth, intended to be evaluated and appreciated, and signs of authority, intended to be believed and obeyed”. In this sense, language as an embodiment of variety of capitals constitutes an epicentre for elite rivalry and competition. The act of competition is performed in what Bourdieu calls linguistic market, where not merely the production and reproduction of linguistic capital takes place, but also its maintenance and possession. Linguistic competence endows one with all capitals: economic, political, social, cultural and symbolic. Therefore, the emergence of the market in two occasions in Eritrea was presented in the paper. Deriving from Bourdieu's conceptualization of the politics of language, it would be possible to infer that power relations stand behind the language controversy in Eritrea, i.e., both implicit and explicit power relations. Power is understood here in its broad sense. The main reason for those elites from Moslem communities that perceive the relation between official language and mother tongue as based on zero-sum, believe that promoting mother tongue would undermine the position of Arabic thereby disproportionally benefiting Tigrinya elites. The assumption derives from the understanding that mother tongues depreciate the value of Arabic by dispersing its component elements. Suppressing mother tongue (the imagined components 
of the entity that is to embody Arabic) and engendering social equilibrium through bilingual official language that produces binary socio-cultural identity would maximize and restore the potential value of Arabic, is the argument of its proponents, which of course is intended to maximize their competitive capacity against the Tigrinyan elites. For the Tigrinyans, the propitious position against the efforts of linguistic equilibrium creation, likewise other mother tongues, is to oppose it. The reason for this is, from pure linguistic perspective, because it depreciates the value of Tigrinya either by subjecting it to domination or undermining its demographic hegemonic position. Moreover, from a socio-political perspective also, it has the potentiality of dividing society along religio-linguistic lines. The bilingual official language strategy intended to be promoted at the expense of mother tongue is then presumed to strengthen the competitive capacity of Arabic. Vesting hegemonic status on Arabic vis-à-vis mother tongue would maximize its competitive capital while at the same time denying mother tongues competitive edge.

Nevertheless, it is important to note that it is not only elites who prefer Arabic to their own vernacular language (mother tongue), but also some of the ethno-linguistic groups too. The groups' language preference is primarily driven by instrumentalist point of view. That gaining competence in Arabic or Tigrinya will increase their children's potential to find employment in the public sphere where Arabic and Tigrinya remain the dominant languages.

The strong opposition to mother tongue in Eritrea draws its inspiration from the assumption that the usage and development of mother tongue in the private as well as public sphere is not only inhibiting Arabic from assuming official status but also allowing Tigrinya to dominate. Tigrinya domination, it is argued, is not merely cultural domination but political domination as well that bestows an unchallenged competitive edge to the Tigrinya speaking elite. This perception derives from the asymmetrical power relation existing between the various ethnolinguistic groups as well as a constructivist perception of social power. The asymmetrical power relation is engendered by demographic asymmetry. According to proponents of this perception the remedy rests on the creation of a socio-cultural equilibrium. A socio-cultural equilibrium that is to be realized by juxtaposing the dominant Tigrinya ethno-linguistic group against the rest that are to be metamorphosed in an Arabic-Islamic socio-cultural supra-ethnic entity.

Finally, it is important here to stress that the inability to separate the question of official language and mother tongue not only has been the greatest impediment to the development of mother tongue but also inhibited a constructive and fruitful discourse of language. 


\section{REFERENCES}

AbaArre, Idris. "Education in Mother-tongue between the Anvil of Popular Rejection and the Hammer of the Academics of the Ministry [of Education]", 2001. Available at: http://www.awate.com/ARTICLES/AbuArre.htm

Agbedor, Paul, “The Language Factor in West Africa's Integration”, in Nation-Building and the Challenges of Regional Integration in West Africa: The case of Ghana, Kwame A. Ninsin (ed). Paris: Karthala, 2009.

Ahmed, Mohamed-Nur, “Our Language and Education”. Presented at a Workshop on National Languages, Asmara, August 16-18, 1996.

Ammar, Wolde-Yesus, Eritrea: Root Causes of War \& Refugees. Baghdad: Sindbad Printing Co., 1992.

Anderson, Benedict. Imagined Communities: Reflections on the origin and spread of nationalism. London New York: Verso, 1991.

Ayafor, I. M. "Colonial Bilingual Heritage and Post-Colonial Myths in Cameroon's School System." Journal of Cultural Studies 3, 1, 2001.

Bender, Lionel M, (ed). "Nilo-Saharan”, in African Languages: An introduction, Bernd Heine and Derek Nurse. Cambridge, New York, Melbourne, Madrid: Cambridge University Press, 2000.

Bereketeab, Redie. Eritrea: The Making of a Nation 1890-1991. Uppsala: Uppsala University, Department of Sociology, 2000.

-.”Supra-ethnic Nationalism.” African Sociological Review 6, 2, 2002.

-. "Perilous Dualism: Language, Religion and Identity in Poly-Ethnic Eritrea”, in, Rights and Politics of Recognition in Africa, Harri Englusnd and Francis Nyamnjoh (eds). London New York: Zed Books, 2004.

-. Eritrea: The Making of a Nation, 1890-1991. Trenton NJ and Asmara: The Red Sea Press, 2007.

Bourdieu, Pierre. Language and Symbolic Power, edited and introduced by John B. Thompson, translated by Gino Raymond and Matthew Adamson. UK: Polity Press, 1991.

Brock-Utne, Birgit. Who see Education For All?: The Recolonization of the African Mind. New York \& London: Falmer Press, 2000

-. "Language, Democracy and Education in Africa”, Discussion Paper 15. Uppsala: Nordiska Afrikainstitutet, 2002.

Cohen, Gideon. "The Development of Regional \& Local Language in Ethiopia's Federal System”, in Ethnic Federalism: The Ethiopian Experience in Comparative Perspective, David Turton (ed). Ohio: Ohio University Press, 2006.

Echu, George. "Colonialism and Linguistic Dilemmas in Africa: Cameroon as a Paradigm (Revisited).” Language \& Culture, An African Journal of Philosophy vol. xiii no, 1-2, 1999.

ELF-RC. "National Democratic Programme of the ELF". The General National Congress, 1989. Eritrean Islamic Salvation Movement (EISM). "Our Charter", 1998. Available at

http://www.alkahlas.org/charter.htm.

Gebre-Medhin, Jordan. Peasants and Nationalism in Eritrea: A Critique of Ethiopian Studies. Trenton NJ: The Red Sea Press, 1989.

Gebremedhin, Yohannes. The Challenges of a Society in Transition: Legal development in Eritrea. Trenton: NJ; The Red Sea Press, 2004. 
Gellner, Ernest. Nations and Nationalism. Oxford UK \& Cambridge USA: Blackwell Publishers, 1983.

Goke-Pariola, Abiodun. "Language and Symbolic Power: Bourdieu and the Legacy of EuroAmerican Colonialism in African Society.” Language \& Communication vol, 13, no. 3, 1993, pp: 219-234.

Gottesman, Les. To Fight and Learn: The Praxis and Promise of Literacy in Eritrea's Independence War. Trenton NJ: Red Sea Press, 1998

Habte Selassie, Bereket. Eritrea and the United Nation. Lawrenceville NJ: Red Sea Press, 1989.

Hayward, Richard J. “Afroasiatic”, in African Languages: An introduction, Bernd Heine and Derek Nurse (eds). Cambridge, New York, Melbourne, Madrid: Cambridge University Press, 2000.

Herman, David. "Ethnolinguistic Identity and Social Cognition: Language prejudice as hermeneutic pathology.” Sign System Studies vol. 35, no.1/2, 2001.

Hobsbawm, Eric J. Nations and Nationalism Since 1780: Programme, myth, reality. New York Port Chester Melbourne Sydney: Cambridge University Press, 1990.

Iyob, Ruth. Eritrean Struggle for Independence: Domination, Resistance, Nationalism. Cambridge: Cambridge University Press, 1995.

Jones, Peter. "Toleration, Recognition and Identity." The Journal of Political Philosophy vol.14, no. 2, 2006.

Kymlicka, Will. "Emerging Western Models of Multination Federalism: Are they relevant for Africa?”, in Ethnic Federalism: The Ethiopian experience in comparative perspective, David Turton (ed). Ohio: Ohio University Press, 2006.

-. Multicultural Citizenship: A liberal theory of minority rights. Oxford: Clarendon Press, 1995.

Kymlicka, Will and Patten, Alan. "Language Rights and Political Theory." Annual Review of Applied Linguistics vol. 23, pp. 3-21, 2003.

Laitin, David D. Nations and States and Violence. Oxford New York: Oxford University Press, 2007.

Lewis, I. M., (ed). Nationalism \& Self Determination in the Horn of Africa. London: Ithaca Press, 1983.

Longrigg, Stephen H. A Short History of Eritrea. London: Oxford University Press, 1945.

Markakis, John. Ethiopia: Anatomy of a Traditional Polity. Oxford: Oxford University Press, 1974.

May, Stephen. Language and Minority Rights: Ethnicity, nationalism and the politics of language. London: Pearson Education, 2001.

Mazrui, Ali A. and Mazrui, Alamin M. The Power of the Babel: Language \& Governance in the African Experience. Oxford: James Currey, 1998.

"Memorandum of the Moslem League", 1947.

Ministry of Information of Eritrea. Eritrea: A country handbook. Asmara: Hidri Publishers, 2002.

Ministry of Education. “Basic Education Statistics 1997/1998”. Asmara, 1998.

Miran, Jonathan. Red Sea Citizens: Cosmopolitan society and cultural change in Massawa. Bloomington and Indianapolis: Indiana University Press, 2009.

Nadel, S. Freddy. "Land Tenure on the Eritrean Plateau.” Africa vol. 16, no. 1, pp.1-21, 1946.

-. "Notes on Beni Amer Society." Sudan Notes and Records vol. 26, pp.51-94, 1945.

Negash, Ghirmai. A History of Tigrinya Literature in Eritrea: The Oral and the Written, 18901991. University of Leiden: Research School of Asian, African, and Amerindian Studies (CNWS), 1999.

Opeibi, B. O. "On Language Model in Ethnic and Inter-group Relations: A Bridge Across Cultures.” Journal of Cultural Studies vol. 2, no. 1, 2000. 
Oster, Nicholas. Empires of the World: A language History of the World. London: HarperCollinsPublishers, 2005.

Patten, Alan. "Political Theory and Language Policy.” Political Theory, vol. 29, no. 5, pp. 691715, 2001.

Prah, Kwesi Kwwa. "Culture, the Missing Link in Development Planning in Africa”. Paper presented at the Roundtable Discussion on: Mainstreaming Human Securing and Conflict Issues in Long-term Development Planning in Africa: A New Development Paradigm? Accra, $9^{\text {th }}-10^{\text {th }}$ July, 2001.

Reaume, D. G. "Official-Languages Rights: Intrinsic Values and the Protection of Difference”, in Citizen in the Diverse Societies, W. Kymlicka and W. Norman (eds). Oxford: Oxford University Press, 2000.

Rokkan, Stein. "Dimensions of State Formation and Nation-Building: A possible paradigm for research or variation within Europe", in The Formation of National States in Western Europe, Charles Tilly (ed). New Jersey: Princeton University Press, 1975.

Smith, Anthony D. State and Nation in the Third World. London: Wheatsheaf Books LTD, 1983.

State of Eritrea. “Constitution of Eritrea.” Eritrea, 1997.

Taylor, Charles. Multiculturalism: Examining the politics of recognition, edited and introduced by Amy Gutman. New Jersey: Princeton University Press, 1994.

Tesfai, Alemseged. "Not by Guns Alone”. A paper presented at the International Conference Against All Odds: Languages and Literature into the 21st Century, Asmara, January 11-17, 2000.

-. Ainfalale (Let's not Divide), 1941-1950. Asmara: Hidri Publishers, 2001.

-. Federashin Ertra mis Etiopia: Kab Matenso Kisab Tedla (Federation of Eritrea with Ethiopia: From Matenso to Tedla), 1951-1955. Asmara: Hidri Publishers, 2005.

The State of Eritrea, Ministry of Education. “Education Brief 1999.” Asmara, 1999.

Thiong'o, Ngugi wa. "Finding Our Way: Dialogue Among Our Languages is the Way to the Unity of African Peoples.” A keynote speech given at the conference Against All Odds: African Languages and Literatures into the $21^{\text {st }}$ Century, Asmara, January 11-17, 2000.

Trevaskis, F. Kendy. Eritrea: A Colony in Transition 1941-52. London New York Toronto: Oxford University Press, 1960.

Tronvoll, Kjetil. Mai Weini: A highland village in Eritrea. Lawrenceville NJ and Asmara: The Red Sea Press, 1998.

Ullendorff, Edward. The Ethiopians: An Introduction to Country and People. London Oxford New York: Oxford University Press, 1973.

Woldemikael, Tekle M. "The Cultural Construction of Eritrean Nationalist Movements”, in The Rising Tide of Cultural Pluralism: The nation-state at bay? Crawford Young (ed). Wisconsin: The University of Wisconsin Press, 1993.

Yohannes, Zemhret. "Homecoming: A Return to Our Languages”. A paper presented at the International Conference Against All Odds: African Languages and Literature into the $21^{\text {st }}$ Century, Asmara, January 11-17, 2000.

Young, Crowford. The African Colonial State in Comparative Perspective. New Haven and London: Yale University Press, 1994.

Young, William C. "The Rashayida Arabs vs. State: The impact of European colonialism on a small-scale society in Sudan and Eritrea." Journal of Colonialism and Colonial History vol. 9, no. 2, Fall 2008.

Webb, Vic. Language in South Africa: The role of language in national transformation, reconstruction and development. Amsterdam/Philadelphia: John Benjamins Publishing Company, 2002. 